REVIEW ARTICLE

\title{
Immunogenic cell death and its therapeutic or prognostic potential in high-grade glioma
}

\author{
Brecht Decraene ${ }^{1,2,3,8}$, Yihan Yang ${ }^{1,4,5,8}$, Frederik De Smet ${ }^{2}$, Abhishek D. Garg (DD ${ }^{6}$, Patrizia Agostinis ${ }^{4,5,8}$ and \\ Steven De Vleeschouwer (iD) ${ }^{1,3,7,8}$
}

(c) The Author(s) 2022

Immunogenic cell death (ICD) has emerged as a key component of therapy-induced anti-tumor immunity. Over the past few years, ICD was found to play a pivotal role in a wide variety of novel and existing treatment modalities. The clinical application of these techniques in cancer treatment is still in its infancy. Glioblastoma (GBM) is the most lethal primary brain tumor with a dismal prognosis despite maximal therapy. The development of new therapies in this aggressive type of tumors remains highly challenging partially due to the cold tumor immune environment. GBM could therefore benefit from ICD-based therapies stimulating the anti-tumor immune response. In what follows, we will describe the mechanisms behind ICD and the ICD-based (pre) clinical advances in anticancer therapies focusing on GBM.

Genes \& Immunity (2022) 23:1-11; https://doi.org/10.1038/s41435-021-00161-5

\section{INTRODUCTION}

Entering the era of immunotherapy, newly-discovered mechanisms breaking the barrier between immunity and cancer have opened the door for novel treatment paradigms. With evidence from several clinical trials, immune checkpoint inhibitors (ICl) have provided promising outcome in certain types of cancers [1-7]. However, immune checkpoint inhibitors only show their effectiveness conditionally within specific biomarker-identified subgroups of patients $[8,9]$. Immunogenic cell death (ICD), discovered in the recent decades, has shed a different light on the relevance of the dialogue established between dying cancer cells and the immune system in cancer therapy [10]. ICD, named after the immunogenicity of dying/dead cancer cells, is a form of regulated cell death $(R C D)$ induced by certain types of therapies. It is able to potentiate adaptive immune responses, targeting residual cancer cells/tissues, through the emission of endogenous molecules that acquire potent immunomodulatory functions when exposed to the extracellular environment, known as damage associated molecular patterns (DAMPs) [11]. Within the process of ICD, specifically associated to apoptotic cell death, the concomitant induction of ROS production [12] and ER stress [13] activate danger signaling, which will lead to the emission of ICD-associated DAMPs in a spatio-temporal manner [14, 15]. Altogether the release of these immunomodulatory molecules, by binding to cognate pattern recognition receptors on the surface of antigenpresenting cells will function as adjuvants to promote their chemotaxis and maturation, which together with the uptake of tumor antigens from dying/dead cells, will culminate in the activation of adaptive immune responses. The ability to activate danger signaling pathways unleashing the proinflammatory/ immunomodulatory potential of DAMPs, is therefore considered the dominant process distinguishing ICD from tolerogenic cell death [16].

ICD is rapidly gaining popularity in the field of anti-cancer therapy. Some conventional treatments have shown to be able to induce some form of ICD [17], and currently, new ICD inducers are under screening $[18,19]$. Besides, some ICD inducers can function in synergy with other types of immunotherapy, such as immune checkpoint inhibitors therapy [20] to enhance their effectiveness.

\section{Main molecular and immunological features of ICD}

To induce cell death with increased immunogenicity, an ICD inducer is necessary in the first place [19-27]. Known therapeutic treatments associated with ICD comprise a variety of cellular stressors, including (but not limited to) conventional chemotherapies (e.g. various anthracyclines), proteasomal inhibitors, oncolytic viruses, and physicochemical/physical stressors such as radiotherapy, photodynamic therapy (PDT), high-hydrostatic pressure [28]. However, with the screening of conventional anti-cancer therapy and the discovery of novel medications for their potential ability to induce ICD, the collection of drugs or treatments associated with a stress-induced RCD with inflammatory and immunogenic features, continues to increase. Based on the molecular knowledge of the signaling pathway triggered by drugs or treatments eliciting cellular stress-associated to ICD, ICD inducers can be classified into two main categories, designated as

\footnotetext{
${ }^{1}$ Research Group Experimental Neurosurgery and Neuroanatomy, Department of Neurosciences, KU Leuven, Leuven, Belgium. ${ }^{2}$ Laboratory for Precision Cancer Medicine, Translational Cell and Tissue Research Unit, Department of Imaging and Pathology, KU Leuven, Leuven, Belgium. ${ }^{3}$ Department of Neurosurgery, University Hospitals Leuven, Leuven, Belgium. ${ }^{4}$ Laboratory of Cell Death Research \& Therapy, Department of Cellular and Molecular Medicine, KU Leuven, Leuven, Belgium. ${ }^{5}$ VIB Center for Cancer Biology

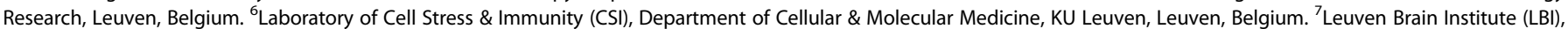
KU Leuven, Leuven, Belgium. ${ }^{8}$ These authors contributed equally: Brecht Decraene, Yihan Yang, Patrizia Agostinis, Steven De Vleeschouwer.

email: steven.devleeschouwer@uzleuven.be
}

Received: 5 November 2021 Revised: 14 December 2021 Accepted: 30 December 2021

Published online: 19 January 2022 
type I and type II. Type I ICD inducers are typified by genotoxic drugs, like anthracyclines, causing the activation of the unfolded protein response and reactive oxygen species production [12] as secondary or collateral cytoplasmic processes evoked in response to damage to their main intracellular target (i.e. DNA). Different from these agents, type II inducers, such as hypericin-mediated PDT, cause ER-focused reactive oxygen species formation, thereby prompting loss of ER homeostasis, intracellular $\mathrm{Ca}^{2+}$ elevation and fast danger signaling pathways eliciting the exposure and release of DAMPs [29-31]. As a result, type II ICD inducers are usually more robust than type I inducers in terms of ICD propensity.

The ER chaperone calreticulin (CRT), is usually translocated from the ER to the plasma membrane during the early phase of ICD as the response of ER stress. The mobilization of CRT to the PM during the early phase of apoptosis has been shown to require loss of the ER-Ca+ store, BAX/BAK, the recruitment of caspase-8, and PERK which partaking the process of unfolded protein response [14]. Depending on the type of ICD, either elF2a the downstream effector of PERK or likely PERK-scaffolding function, has been found to be crucial for CRT trafficking to the plasma membrane [32]. Once exposed at the surface CRT acts as potent 'eat-me" signal, by binding to CRT cognate receptor on antigenpresenting cells, and facilitates the engulfment of dying cells by DCs. Clinical studies have shown that, in human non-small cell lung cancers, the expression level of CRT is also positively correlated with accumulation of matured DCs and the survival of patients [33]. In neuroblastoma, expression of CRT can be used as an independent prognostic factor [34], suggesting the biomarker potential of CRT.

Adenosine triphosphate (ATP), is secreted during a pre-mortem phase of ICD. During ICD, ATP secreted by stressed cells, by binding to purinergic receptors (P2RY2 and $P 2 R X 7)$ on the surface of DCs, acts as 'find-me" signal to recruit DCs to the site of dying cancer cells and stimulates the assembly and activation of the inflammasome, leading to the production and secretion of interleukin (IL)-1 $\beta$ [35] by DCs. The pathway causing ATP release from stressed cancer cells is, however, dependent on the type of ICD inducers. Autophagy has been shown to be either required for ATP release in response to anthracyclines, or be dispensable in case of Hypericin-PDT [31]. In the last settings, autophagy induction after Hypericin-PDT by eliminating oxidatively damaged proteins, attenuated ER stress, and the exposure of CRT [31]. In contrast, Prieto et al. showed that in response to P2Et extract from the plant Caesalpinia spinosa, autophagy occurs before apoptotic cellular demise to promote ecto-CRT [36] and further immune response will be elicited during the progression of ICD [31]. Hence the role of autophagy in ICD remains highly context-dependent.

In the post-demise phase of ICD, nuclear HMGB1 is relocated to the cytoplasm and will be exposed extracellularly upon plasma membrane rupture. This passive released HMGB1, during the later stage of apoptosis and secondary necrosis, stimulates tumor antigen presentation DC maturation by binding toll-like receptor 4.

Besides these DAMPs which have an intracellular housekeeping function, other danger molecules can be transcriptionally induced during ICD. For example, certain type of ICD inducers, triggers type I interferon (IFN) responses and the secretion of several chemokines [37] with a pronounced immunomodulatory role. It is thought that stimulation of type I IFN activity is one of the reasons why ICD can function synergistic with anti-PD1 therapy [38]. For example, radiotherapy induction of type I IFN can overcome the resistance of anti-PD1 [39]. On the other hand, since persistent type I IFN response will lead to immunosuppression only ICD inducers that cause transient type I IFN release may possess the beneficial effect of stimulating anti-tumor immunity. In line with this, dinaciclib, a cyclin-dependent kinases inhibitor that can induce a proper amount of type I IFN release in a timely manner, alleviates the resistance to checkpoint-blockade treatment $[20,40]$. Intriguingly, a recent study shows that transcriptional pro-inflammatory signature is shared by both anthracyclines and Hypericin-PDT, and distinguishes ICD from non-ICD (e.g. Cisplatin) regimens. This ICD-associated response, which is driven by the activation of NF-kB and AP-1 transcritption factors coordinated by heat shock protein 60 [37] is critical for the anticancer vaccination potential of ICD-inducing chemotherapy.

However, it should be noticed that both ICD-associated DAMPs and various cytokines and chemokines induced by ICD can have profound and sometimes contrasting impact on the TME. Surface exposed calreticulin for example promotes tumor antigen presentation by facilitating DC phagocytosis, but can also promote cancer cell invasion [41]. HGMB1 stimulates DC maturation, however, its immunomodulatory activity is dependent on its oxidation status [42] and its role is tumor and TME specific [43]. Extracellular ATP acts as a chemoattractant for immature DCs but can be converted into an immunosuppressive form (adenosine) by CD39 (ecto-nucleoside triphosphate diphosphohydrolase 1) and CD73 (ecto-5'-nucleotidase). CD39 performs the first step converting ATP into AMP and CD73 further converts it into adenosine. Furthermore, both enzymes regulate the magnitude of the purinergic reaction surrounding the immune cells. High expression of CD73 is therefore associated with low levels of lymphocytes in the TME and poor prognosis in for example colorectal, prostate, and triple-negative breast cancer [44-47]. Of note, CD73 is regulated by HIF-1alpha and therefore more abundant in a hypoxic microenvironment [48]. Finally, ICD may exert several effects on the TME [49]. Phagocytosis of ICD-dying tumor cells by DC will elicit full DC maturation, and release of immunogenic cytokines (e.g., IL-6, IL-2,...), which in turn will promote differentiation and proliferation of CD4+ and CD8+ T lymphocytes and thus ameliorate the adaptive immune response. Tumoral DCs are therefore associated with a more favorable prognosis [33]. Apart from that, as mentioned above, various anticancer regimens may cause the secretion of type I IFN by dying cancer cells which will further favor $T$ lymphocyte recruitment and the establishment of a strong adaptive anticancer immunity. A pleiotropy of antitumor effects is kickstarted by those T-cells ranging from stimulatory feedback loops to IFN release (which has an anti-angiogenic, anti-proliferative, and proapoptotic effect) and from complex interactions between subtypes of mainly $T$ lymphocytes, resulting in antitumor attacks, to chemokine expression (CXCR3) which attracts other immune cells towards the tumor. Also the latter effect may be indirectly caused by IFN [50]. Furthermore, a neutrophilic inflammation reaction is also seen in ICD [51].

\section{Immunogenicity of different types of RCDs}

Before the discovery of ICD, apoptosis was generally interpreted as non-immunogenic regulated cell death manner (Table 1). However, in autoimmune diseases, apoptotic cellular antigen has long been identified as a target of autoantibodies in autoimmune diseases, which hints the relation between apoptosis and immunity $[52,53]$. Early study showed that under certain subclass of therapies, apoptosis induced can be immunogenic and proinflammatory [54]. Subsequent studies have demonstrated that using various ICD inducers, apoptotic cancer cells can be used as cancer vaccines causing tumor regression to different extents in different cancers. However, as mentioned above, other types of RCD typically associated to more robust inflammatory responses, have been shown to elicit ICD.

Necroptosis is "programmed" by the activation/phosphorylation of receptor-interacting protein kinase-1 (RIPK-1), RIPK-3, and mixed lineage kinase domain-like pseudokinase regulated pathway, ultimately causing the permeabilization of plasma membrane [55], Necroptosis is an alternative RCD that could elicit ICD [56] especially in apoptosis-resistant cancer cells subpopulations [57-59]. Under certain circumstances, necroptotic cancer cells 
Table 1. Studies on immunogenicity/ICD potential of different types of RCDs.

\begin{tabular}{|c|c|c|c|c|}
\hline Study & ICD inducer & PCD & DAMPs & $\begin{array}{l}\text { Other proof of } \\
\text { immunogenicity }\end{array}$ \\
\hline Tesniere et al. (2010) [25] & Oxaliplatin (OXP) & Apoptosis & Ecto-CRT, HMGB1 & \\
\hline Koks et al. (2015) [136] & Newcastle disease virus (NDV) & Necroptosis & $\begin{array}{l}\text { Ecto-CRT, ATP, HMGB1, } \\
\text { HSP70, and HSP90 }\end{array}$ & \\
\hline Teo et al. (2017) [140] & $\begin{array}{l}\text { BYL719 (PI3Ka inhibitor) + LEE011(CDK4/6 } \\
\text { inhibitor) }\end{array}$ & Apoptosis & Ecto-CRT & \\
\hline Hossain et al. (2018) [20] & Dinaciclib & Apoptosis & Ecto-CRT, ATP, and HMGB1 & \\
\hline Li et al. (2018) [137] & $\begin{array}{l}\text { Doxorubicin-polyglycerol-nanodiamond } \\
\text { composites }\end{array}$ & Apoptosis & $\begin{array}{l}\text { Ecto-CRT, HMGB1, } \\
\text { and HSP90 }\end{array}$ & DC maturation \\
\hline Turubanova et al. (2019) [21] & Photosens & $\begin{array}{l}\text { Apoptosis and } \\
\text { ferroptosis }\end{array}$ & Ecto-CRT, ATP, and HMGB1 & IL-6 \\
\hline $\begin{array}{l}\text { Franco-Molina et al. (2020) } \\
\text { [141] }\end{array}$ & Panobinostat (PAN) & Apoptosis & $\begin{array}{l}\text { HMGB1, HSP70, } \\
\text { and HSP90 }\end{array}$ & \\
\hline $\begin{array}{l}\text { Franco-Molina et al. (2020) } \\
\text { [141] }\end{array}$ & Lophophora williamsii (LW) & Apoptosis & $\begin{array}{l}\text { HMGB1, HSP70, } \\
\text { and HSP90 }\end{array}$ & \\
\hline Jeong et al. (2021) [23] & $\begin{array}{l}\text { Fluorinated mitochondria-disrupting } \\
\text { helical polypeptides (MDHPs) }\end{array}$ & Apoptosis & Ecto-CRT, ATP, and HMGB1 & \\
\hline Villamañan et al. (2021) [142] & $\begin{array}{l}\text { Temozolomide (TMZ) }+ \text { CX-4945 (protein } \\
\text { kinase CK2 inhibitor) }\end{array}$ & Unspecified & Ecto-CRT and ATP & \\
\hline Turubanova et al. (2021) [22] & Porphyrazines (pz l)-PDT & Apoptosis & ATP and HMGB1 & DC maturation \\
\hline Turubanova et al. (2021) [22] & Porphyrazines (pz III)-PDT & $\begin{array}{l}\text { Apoptosis and } \\
\text { Necroptosis }\end{array}$ & ATP and HMGB1 & DC maturation \\
\hline
\end{tabular}

can induce ATP secretion and CXCL1 release, become phagocytized by DCs and stimulate their maturation. To be noted, in the study of Aaes et al. [60], necroptotic cancer cells failed to cause ER stress and the translocation of CRT from ER to plasma membrane. Further in vivo study validated that necroptotic cancer cells can induce a potent immune response by the cross-priming, proliferation, and cytokine release of cytotoxic T-cells [56]. Moreover, necroptosis has been shown to result in a higher presence of CD8 + T-cells and to reduce the number of myeloidderived suppressor cells in pancreatic tumors [61].

Over the last decade more types of RCD have been defined and their immunogenicity was subsequently studied. Ferroptosis, an iron-mediated and lipid peroxidation-driven necrotic cell death, can induce the secretion of ATP and the release of HMGB1 in fibrosarcoma and glioma [62]. However, the immunomodulatory function of ferroptosis may depend on the cell death stage. A recent study shows that, only in the early stage, ferroptosis can promote the maturation of DCs, but not in the late stage [62]. Hence whether, when, and how ferroptosis might open another door of prompting ICD, especially when other RCDs are 'silenced" in cancer cells is still unclear. More in-depth studies are needed to further understand the mechanistic underpinnings of this form of RCD and its impact on immune responses.

Besides, different types of RCD can exist simultaneously in ICD induced by a single inducer. Turubanova et al. showed that in photosens -PDT induced ICD, cell death can be inhibited by both zVAD-fmk (apoptosis inhibitor) and ferrostatin-1 and DFO (ferroptosis inhibitors), which means apoptosis and ferroptosis are co-existing during the process [22]. Further research on the cross-talk of different RCDs is warranted [63]. Moreover, the antitumor immunity potential of other genetically defined necrotic cell death processes, like secondary necrosis, pyroptosis, and PANoptosis, which integrates pyroptosis, apoptosis, and necroptosis into a unified programmed cell death behavior, is currently under investigation [64].

\section{Cell autonomous mechanisms of ICD evasion}

A hallmark of cancer cells is evasion from the surveillance of the immune system [65]. While various cancer cell autonomous and non-autonomous factors contribute to this complexity and are still under investigation, it is intriguing that tumor cells may evade ICD by the chronic deregulation of processes regulating cell proteostasis, such as the unfolded protein response and autophagy, that contributes to the immunogenicity of the stressed/dying cancer cells. Clearly, acute activation of the lethal arm of ER stress by therapy-induced cellular stress and death pathway, harness the "danger" component of this stress response, in a fashion similar to that induced by microbial pathogens, thus turning sterile cancer cell death into a mimicry of pathogen-induced cell demise, with consequent activation of immune responses.

However, certain cancer cell autonomous mechanisms regulating proteostasis can either subvert danger signaling pathways (like the PERK-eiF2 $a$ axis [66]), cause retention of DAMPs thereby impairing the proficient dialogue between dying cancer cells and the immune system or secrete mutate forms of DAMPs (like mutant (RT) which supposed to act as a decoy for DCs in the wildtype [67]. For example, in glioma Bip upregulation, a typical marker of the activation of the unfolded protein response, 
restricted DAMPs exposure and release in glioma stem cells [68]. A recent study also reported that cancer cells may avoid the exposure of CRT through a mechanism involving stanniocalcin-1 mediated retention of CRT in the cytoplasm (thus suggesting a pool of cytosolic (RT), a process that impairs phagocytosis by antigenpresenting cells and subsequent anticancer adaptive immunity [67]. Hence, strategies designed to target deranged proteostasis in cancer cells in order to reinstate the cancer cell-immune cell dialogue, will require an increased knowledge of the inhibitory elements of the danger signaling pathway elicited by ICD.

\section{ICD and Glioblastoma}

Glioblastoma, a grade IV glioma, is the most aggressive type of primary brain tumor with a dismal prognosis of approximately 15 months under standard of care therapy which consists of maximal safe surgical resection followed by both radiotherapy and chemotherapy (Temozolomide) [69, 70]. However, a minority of patients, estimated to be around 3\% of all GBM patients, can live up to five years or longer [71]. This contributes to the new vision on GBM where it is not considered to be one fixed entity but rather an inter- and intrapersonal heterogeneous tumor behaving differently among patients. Several immunological reasons for the poor prognosis in GBM have been postulated. Amongst these the most important ones seem the GBM-associated lymphopenia, the "cold state" of these tumors depriving them from effector T-cell infiltration, their inability to become fully activated, and the formerly mentioned heterogeneity [72]. Over the past years there has been increasing evidence pointing towards the propensity to undergo ICD as a prognostic factor linked with longer survival in cancer patients in general including GBM patients [3]. Fitting in the "heterogeneity picture" there is the observation that a tumor with a higher ICD propensity could elicit a stronger anti-tumor immune response and as such could combat and slow down tumor growth more efficiently [73]. Subsequently, this would also result in a stronger anti-tumor 'self-vaccine" response (Fig. 1).

The GBM tumor microenvironment consists of tumor cells (from glioma stem cells to fully differentiated tumor cells), resident (microglia), and infiltrating immune cells (in GBM mainly macrophages and much less T-lymphocytes), structural stromal (endothelial, astrocytes, oligodendrocytes), and neuronal cells. Whereas the direct, innate immune response (which consists of cells like macrophages, a few NK cells, and others) is the first line of defense against tumor cells, it also primes a more precise and stronger response called 'the adaptive immune response' (of which lymphocytes are the main cell type). This response recognizes tumor antigens presented by the proper major histocompatibility complex (MHC) molecules. Although in broad terms of e.g. T-cell infiltration, the immune framework in most GBMs looks similar, the exact immune cell composition of the tumor microenvironment varies over time (for example primary versus recurrent GBMs) and space ("intratumoral heterogeneity") [74]. The latter indirectly implies the complexity of all possible interactions that can take place between immune and/or tumor cells within the tumor microenvironment. Furthermore, the constitution can also be modified by external factors, like chemo-or radiotherapy [75, 76].

Certain therapies used in the treatment of brain tumors, can induce the main cell death-associated hallmarks of ICD [27, 77]. pushing the final effect on the tumor beyond the results of the initiating therapeutic mechanisms of e.g chemo-and radiotherapy. [4] However, how GBM heterogeneity and the associated tumor microenvironment enact cancer cell-intrinsic resistance mechanisms blunting the responses to potential ICD-inducing regimens remains incompletely understood.

\section{ICD-inducing modalities in GBM}

Several treatment modalities can induce ICD and thus an anticancer immune response reinforcing the effects of conventional treatment methods (Table 2). However, so far only a few bona fide ICD inducers have been identified and were tested in clinical trials $[78,79]$.

Photodynamic therapy (PDT) has been tested in several cancers, among which GBM [80]. One large review of literature looking at over 1000 patients in several observational studies concluded PDT to be a safe and beneficial treatment method leading to a significant prolongation of good quality survival [81]. However, the quality of the included studies is limited as no randomized controlled trials are performed yet. Moreover, it is worth mentioning that PDT is less effective in the hypoxic niche, as well that it itself exacerbates hypoxia $[82,83]$. Currently, different strategies are being developed to tackle this issue [84-86]. It is to notice that one of the main forms of PDT is 5-aminolevulinic acid which is a prodrug metabolized in high grade glioma into a fluorescent metabolite and commonly used to guide maximal safe resection in newly diagnosed and recurrent GBM [87].

Radiotherapy was also found to possess ICD inducing properties in several cancers [88]. It can render the tumor microenvironment more immunogenic by increasing MHC and cell death receptor expression thereby improving the killing of irradiated tumor cells by NK cells and T-cells [89]. It further expresses chemokines

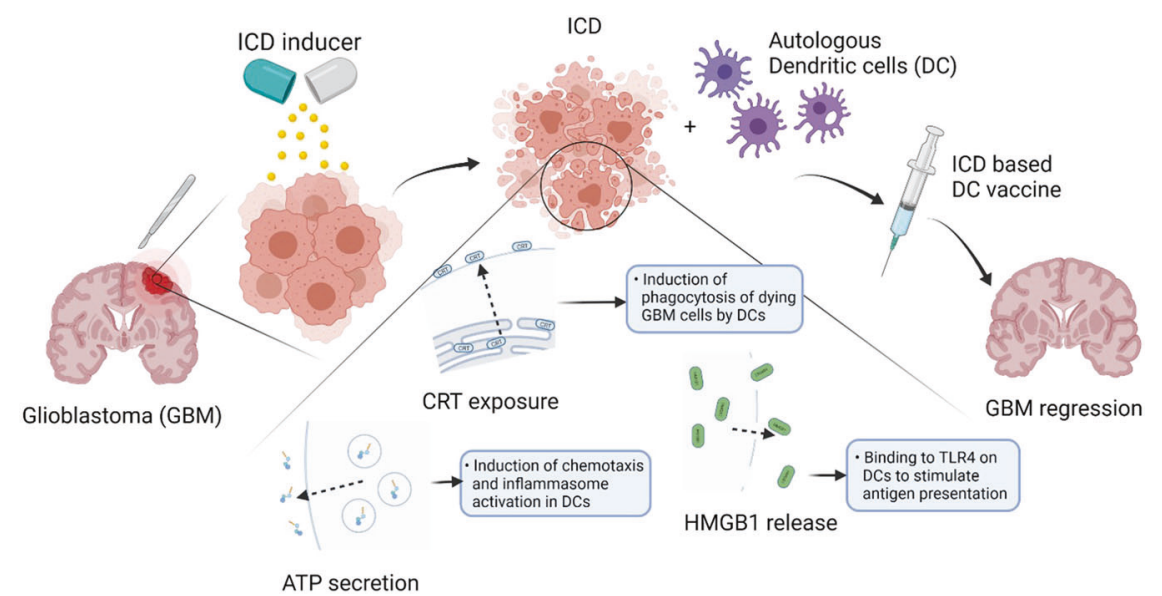

Fig. 1 Clinical setting of ICD-based GBM vaccination. After GBM resection, ICD will be induced using GBM cells from resected tumor tissue. Next, DC vaccine are prepared ex vivo by exposing autologous DCs to GBM cells dying through ICD. The vaccine contains GBM cells, which are avitalized after ICD induction, and DAMPs, which are either exposed, secreted or released. After applying to the patient, with tumor antigen presented by DCs, effective and GBM-specific T-cell response will be triggered and augmented. Remaining GBM cells will then be targeted to suppress GBM growth and regression. As a result, prolonged survival of the patient might occur. 


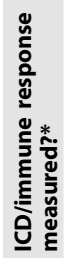
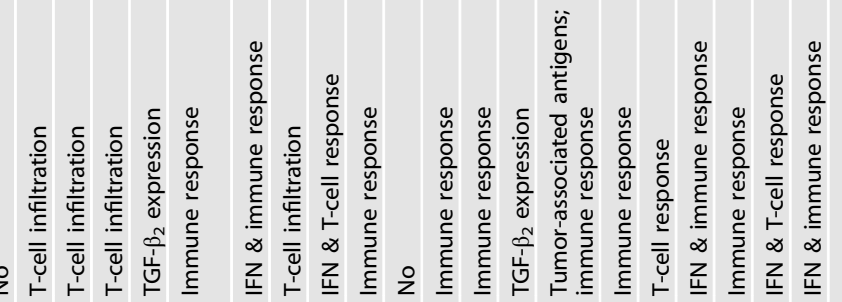

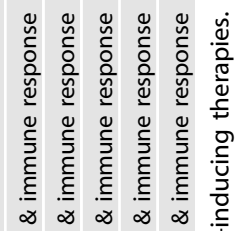

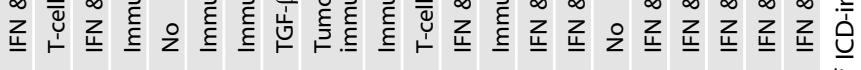

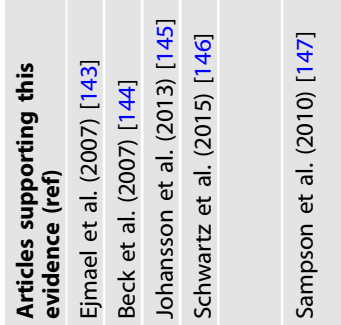

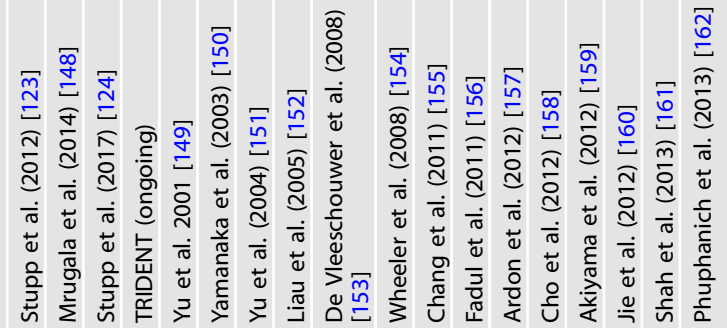

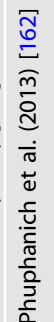

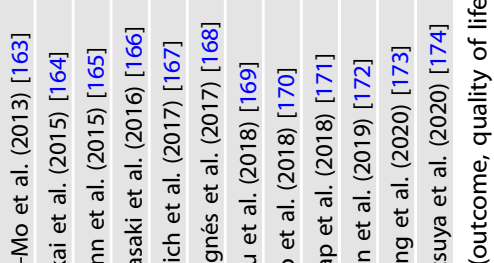

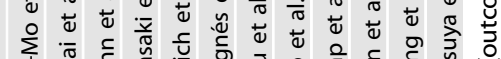

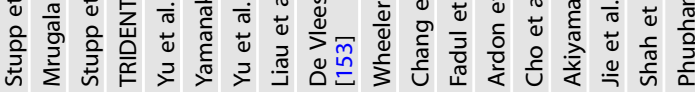

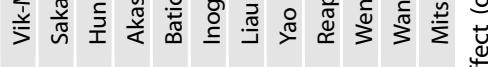

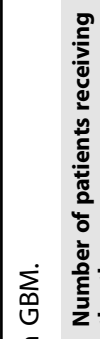

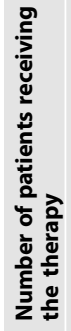

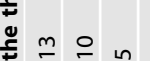

ส

$\frac{1}{0}$

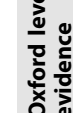

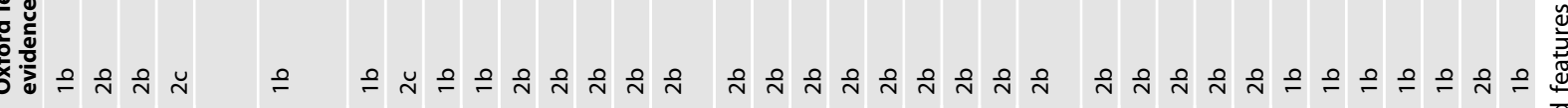

¿

苞

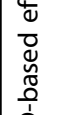

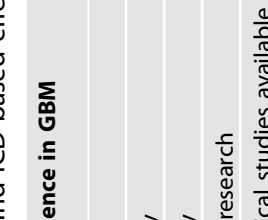

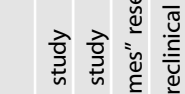

$\frac{\frac{0}{0}}{\frac{0}{0}}$

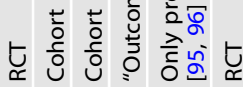

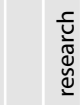

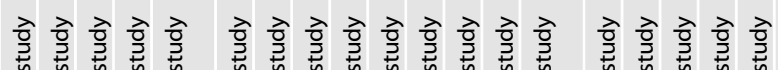

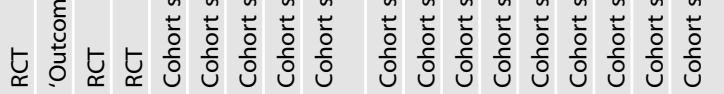

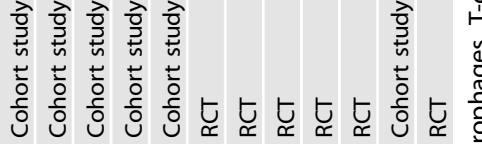

$\frac{\sqrt{2}}{\frac{\sqrt{n}}{4}}$

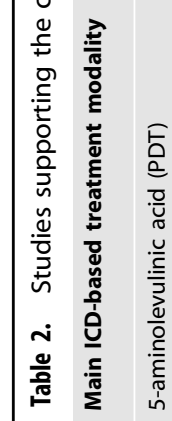
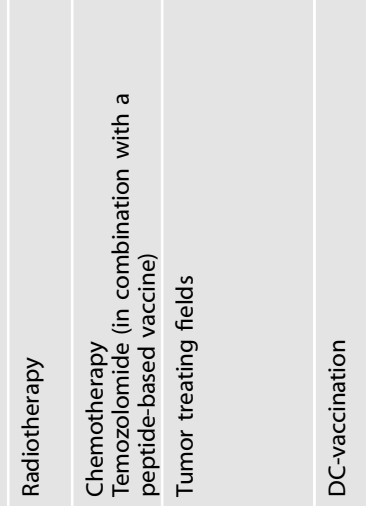

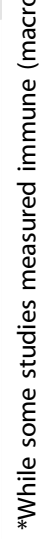


(CXCL16) and increases IFN $-\gamma$ production contributing to T-cell infiltration and recognition of tumor cells by CD8+ T-cells [90-92]. Up till now, a biomarker to predict the ICD inducing capacity of Radiotherapy in cancer has not been identified [93]. Radiotherapy as a standalone ICD inducer is rarely studied in clinical trials and the potential benefit is more often explored in combinational treatment methods. E.g., in breast cancer, the combination of radiotherapy and Imiquimod (a topical TLR7 agonist) decreases recurrence rates and improves primary tumor response [94]. By analyzing the concentration of HMGB1 and of Hsp70 in supernatants of glioblastoma cell cultures treated with fractionated Radiotherapy an increase in these DAMPs was seen $[95,96]($ In this studies the ICD inducing capacity of temozolomide was found to be limited). Up till now, no clinical trials have been performed in glioma.

Several chemotherapeutic agents have shown to induce ICD; paclitaxel, anthracyclines, and anthracycline-derivatives with bleomycin and doxorubicin being the most known ones $[27,97,98]$. In glioma mouse models cyclophosphamide was found to initiate ICD, but evidence in glioma patients is lacking [99]. Furthermore, prolonged oxaliplatinum treatment resulted in elevated translocation of calreticulin to the cell surface in glioma cells [100]. It is also worth mentioning that not all chemotherapeutic agents induce ICD, although the exact mechanism why some do and others don't is still under investigation. Furthermore, an extrapolation of the ICD inducing ability of chemotherapeutic agents in extracranial cancers to brain tumors is not correct. While for example platinum compounds like cisplatinum induce ICD in several extracranial cancers, this effect was not seen in primary brain tumors $[25,101]$. Studies investigating the effect of ICDinducing chemotherapeutic Oxaliplatin in combination with oncolytic viruses in colorectal cancer in mice saw an additional effect leading to diminished tumor growth and longer median survival [102]. This is in line with earlier studies showing the ICD inducing capacity of oncolytic viruses [103, 104].

Chemotherapeutic drugs loaded in a tumor microenvironment -responsive nanoparticle and injected into a tumor improved the ICD effect, released more DAMPs, or increased immune infiltration of DCs and T lymphocytes compared to free delivered drugs [105]. In PTEN-negative orthotopic GBM epirubicin-loaded micelles in combination with anti-PD1 therapy overcame the weakening of antitumor effects of immune checkpoint inhibitors normally caused by lymphodepletion when administered systemically [106]. Another nanotechnique used is called 'nanopulse stimulation". Here a very short electrical pulse is repeatedly administered at a high amplitude to the tumor, subsequently triggers ER stress, and therefore acts as an ICD-inducer [107]. However, both nanotechniques are still in their infancy.

Near-infrared photoimmunotherapy is another recently developed technique. This hybrid technique consists of an antibody that targets specific tumor antigens and a photo-activating, phthalocyanine-based chemical, IRDye700DX that attracts the NIR light. This light triggers cytotoxic reactions in the targeted cancer cells causing ICD [108]. Increased levels of DAMPs were seen when near-infrared photoimmunotherapy was applied implying its ICD inducing effect. Further clinical trials are on their way.

Other less known ICD inducers are high hydrostatic pressure and hyperthermia. High hydrostatic pressure induces the expression on the cell surface and the release of DAMPs on a wide variety of human tumor cells (leukemia, ovarian cancer, and prostate cancer) [109]. Hyperthermia (ranging from $41^{\circ} \mathrm{C}$ to $44^{\circ} \mathrm{C}$ ) includes local as well as whole body administration of heat. It has several effects on the tumor microenvironment including improvement of antigen presentation, maturation, and migration of DCs, and also facilitates migration of T-cells to lymph nodes. The main disadvantage is collateral damage of the heat to nontumoral regions, although the nanoparticle carrier technique discussed above is being explored here as well. The clinical significance of this technique is currently limited to combination treatments with chemotherapy or immunotherapy and the radiosensitization effect of hyperthermia. Studies were done in breast, gastrointestinal, cervical, and head-\&-neck cancer [110114]. In the brain, induction of hyperthermia is being hampered by obvious safety constraints but with more accurate thermal monitoring tools, controlled hyperthermia is being explored in brain tumors as well. Examples are laser interstitial thermal therapy and high-intensity focused ultrasound. Laser interstitial thermal therapy is a percutaneous ablative procedure in which thermal laser energy is delivered via an optic fiber probe precisely into the tumor under stereotactic guidance [115]. It is being used in several brain tumors, especially in non-resectable GBM, although large clinical trials concerning the exact benefit and application are still lacking. High-intensity focused ultrasound is another non-invasive intracranial ablation technique in which a focused beam of ultrasound rays is targeted at a limited tumoral region to maximize local energy accumulation causing tumoral tissue destruction [116]. Several small case studies have been published showing a survival advantage using this technique in GBM patients [117-119]. However Medel et al.,61 postulated that GBM might not be the ideal pathology for this treatment modality and it might be more successful for well-circumscribed tumors, such as metastases or low-grade brain tumors, where surgery cannot be performed [120,121].

Also, it was discovered that certain targeted drugs, epidermal growth factor receptor inhibitors and tyrosine kinase inhibitor Crizotinib, might also exert an ICD inducing effect although both have only been tested in mice [18, 122].

Specifically, for GBM, 'Tumor treating fields" is a novel clinically integrated treatment modality with ICD potential [123-125]. This technique, first described in 2004, uses very-low-intensity, intermediate-frequency alternating electrical fields that exert several antitumoral effects. The induction of ICD is one of the key mechanisms behind this therapy, next to neovascularization, antimitotic activity, and inhibition of cancer cell migration, invasion, and proliferation [125]. It was proven to be both effective and safe in GBM-patients in two-phase three RCTs $[123,124]$. Although tumor treating fields showed an increase in overall survival in both newly diagnosed and recurrent GBM, the preferable combination with other currently used anticancer modalities should be further investigated [126].

Another promising technique is DC-based vaccination (Fig. 1). In a high-grade glioma mouse model harnessing the potential of Hypericin-PDT based DC vaccines, these vaccines reduced the immunosuppressive GBM burden and synergized with the antiGBM action of temozolomide and resulted in an increased overall mice survival of approximately 300\% [127] Interestingly, the efficacy of stressed/dying cells after Hypericin-PDT to induce DC maturation and the overall efficiency of DC vaccines, were abolished by the neutralization of the main ICD-associated DAMPs namely HMGB1, ATP and CRT [128]. This is in line with the finding that, in contrast to anthracyclines or other regimens, Hyp-PDT mediated ICD is not associated to the stimulation of Type I IFN responses $[16,129,130]$. Considering that in about 50\% GBM patients, type I and/or type II IFN family genes are deleted intrinsically [131], this suggests that Hypericin-PDT elicited immunogenicity will not be compromised and should be considered for its potential clinical application in GBM.

Several, mostly small, clinical trials have been published (Table 1). In general, they point towards a small benefit in terms of survival in combination with other treatment modalities. However, substantial and significant improvements were not yet found. The heterogeneity in-between GBM tumors may be a possible underlying explanation in the discrepancy seen in vaccine responses.

Another recent experimental technique described in a GBM mouse models is an injectable hydrogel system that can be delivered into the postsurgical tumor cavity. It subsequently 
induces ICD and results in a sustained T-cell infiltration, therefore mimicking a hot tumor immune environment which combats local tumor remnants, preventing recurrence. Both a prolonged survival and decreased tumor relapse were seen [132].

Other less known ICD-based techniques that are currently being developed are genetically engineered viruses (oncolytic viruses), which uses viral vectors (and thus unable to replicate) to deliver cytotoxic material to the tumor cells resulting in ICD [133-135]. Also naturally occurring oncolytic viruses have been described [136]. Another modality are protein kinase CK2 inhibitors, which shows already at low concentrations cytotoxic activity in GL261 GB cells, inducing ICD; DC-mediated delivery of doxorubicin-polyglycerolnanodiamond composites, a potent DAMPs inducer [137]; as well as liposomes modified to cross the blood-brain barrier and loaded with the chemotherapeutic drug Doxorubicin [138].

Finally, although necroptotic components were found in GBM, the influence on the immune environment was to our knowledge never examined [139].

\section{CONCLUSION}

ICD is rapidly gaining research momentum as a key-mechanism to pursue in effective and sustainable cancer therapies. Current evidence of its importance in glioma therapies is often indirect, scattered and inconclusive but in analogy with many other tumor types, ICD propensity could become a pivotal prognosticator for long-term disease control and continues to capitalize on its -at least theoretical -potential for cure.

\section{REFERENCES}

1. Larkin J, Chiarion-Sileni V, Gonzalez R, Grob JJ, Cowey CL, Lao CD, et al. Combined Nivolumab and Ipilimumab or Monotherapy in Untreated Melanoma. N. Engl J Med 2015;373:23-34.

2. Emens LA, Adams S, Barrios $\mathrm{CH}$, Diéras V, Iwata $\mathrm{H}$, Loi $\mathrm{S}$, et al. First-line atezolizumab plus nab-paclitaxel for unresectable, locally advanced, or metastatic triple-negative breast cancer: IMpassion130 final overall survival analysis. Ann Oncol 2021;32:983-93.

3. Fucikova J, Moserova I, Urbanova L, Bezu L, Kepp O, Cremer I, et al. Prognostic and Predictive Value of DAMPs and DAMP-Associated Processes in Cancer. Front Immunol 2015;6:402.

4. Fucikova J, Kepp O, Kasikova L, Petroni G, Yamazaki T, Liu P, et al. Detection of immunogenic cell death and its relevance for cancer therapy. Cell Death Dis 2020;11:1013.

5. Ferris RL, Blumenschein G, Fayette J, Guigay J, Colevas AD, Licitra L, et al. Nivolumab for Recurrent Squamous-Cell Carcinoma of the Head and Neck. N. Engl J Med 2016;375:1856-67.

6. Hellmann MD, Paz-Ares L, Bernabe Caro R, Zurawski B, Kim S-W, Carcereny Costa E, et al. Nivolumab plus Ipilimumab in Advanced Non-Small-Cell Lung Cancer. N. Engl J Med 2019;381:2020-31.

7. Ott PA, Hu-Lieskovan S, Chmielowski B, Govindan R, Naing A, Bhardwaj N, et al. A Phase lb Trial of Personalized Neoantigen Therapy Plus Anti-PD-1 in Patients with Advanced Melanoma, Non-small. Cell Lung Cancer, or Bladder Cancer Cell. 2020;183:347-60.e24.

8. Overman MJ, McDermott R, Leach JL, Lonardi S, Lenz HJ, Morse MA, et al. Nivolumab in patients with metastatic DNA mismatch repair-deficient or microsatellite instability-high colorectal cancer (CheckMate 142): an open-label, multicentre, phase 2 study. Lancet Oncol 2017;18:1182-91.

9. Vanmeerbeek I, Borras DM, Sprooten J, Bechter O, Tejpar S, Garg AD. Early memory differentiation and cell death resistance in $T$ cells predicts melanoma response to sequential anti-CTLA4 and anti-PD1 immunotherapy. Genes Immun 2021;22:108-19.

10. Galluzzi L, Vitale I, Warren S, Adjemian S, Agostinis P, Martinez AB, et al. Consensus guidelines for the definition, detection and interpretation of immunogenic cell death. J Immunother Cancer. 2020;8:1-22.

11. Garg AD, Galluzzi L, Apetoh L, Baert T, Birge RB, Bravo-San Pedro JM, et al. Molecular and translational classifications of DAMPs in immunogenic cell death. Front Immunol 2015;6:1-24.

12. Moserova I, Truxova I, Garg AD, Tomala J, Agostinis P, Francois P. Caspase-2 and oxidative stress underlie the immunogenic potential of high hydrostatic pressure-induced cancer cell death. Oncoimmunology. 2017;6:1-12.
13. Verfaillie T, Vliet A, Van, Garg AD, Dewaele $M$, Rubio $N$, et al. Biochemical and Biophysical Research Communications Pro-apoptotic signaling induced by photo-oxidative ER stress is amplified by Noxa, not Bim. Biochem Biophys Res Commun 2013;438:500-6.

14. Garg AD, Krysko DV, Verfaillie T, Kaczmarek A, Ferreira GB, Marysael T, et al. A novel pathway combining calreticulin exposure and ATP secretion in immunogenic cancer cell death. EMBO J 2012;31:1062-79.

15. Panaretakis T, Kepp O, Brockmeier U, Tesniere A, Bjorklund AC, Chapman DC, et al. Mechanisms of pre-apoptotic calreticulin exposure in immunogenic cell death. EMBO J 2009;28:578-90.

16. Garg AD, Agostinis P. Cell death and immunity in cancer: From danger signals to mimicry of pathogen defense responses. Immunol Rev 2017;280:126-48.

17. Hodge JW, Garnett CT, Farsaci B, Palena C, Tsang KY, Ferrone S, et al. Chemotherapy-induced immunogenic modulation of tumor cells enhances killing by cytotoxic $T$ lymphocytes and is distinct from immunogenic cell death. Int J Cancer. 2013;133:624-36.

18. Liu P, Zhao L, Pol J, Levesque S, Petrazzuolo A, Pfirschke $C$, et al. Crizotinibinduced immunogenic cell death in non-small cell lung cancer. Nat Commun 2019;10:1486.

19. Huang KCY, Chiang SF, Yang PC, Ke TW, Chen TW, Hu CH, et al. Immunogenic cell death by the novel topoisomerase $\mathrm{i}$ inhibitor tlc388 enhances the therapeutic efficacy of radiotherapy. Cancers (Basel). 2021;13:1-14.

20. Md Sakib Hossain D, Javaid S, Cai M, Zhang C, Sawant A, Hinton M, et al. Dinaciclib induces immunogenic cell death and enhances anti- PD1-mediated tumor suppression. J Clin Invest 2018;128:644-54.

21. Turubanova VD, Balalaeva IV, Mishchenko TA, Catanzaro E, Alzeibak R, Peskova $\mathrm{NN}$, et al. Immunogenic cell death induced by a new photodynamic therapy based on photosens and photodithazine. J Immunother cancer. 2019;7:350.

22. Turubanova VD, Mishchenko TA, Balalaeva IV, Efimova I, Peskova NN, Klapshina LG, et al. Novel porphyrazine-based photodynamic anti-cancer therapy induces immunogenic cell death. Sci Rep. 2021;11:1-13.

23. Jeong SD, Jung BK, Ahn HM, Lee DY, Ha JH, Noh I, et al. Immunogenic Cell Death Inducing Fluorinated Mitochondria-Disrupting Helical Polypeptide Synergizes with PD-L1 Immune Checkpoint Blockade. Adv Sci 2021;8:1-13.

24. Tomic S, Petrovic A, Puac N, Škoro N, Bekic M, Petrovic ZL, et al. Plasmaactivated medium potentiates the immunogenicity of tumor cell lysates for dendritic cell-based cancer vaccines. Cancers (Basel). 2021;13:1626.

25. Tesniere A, Schlemmer F, Boige V, Kepp O, Martins I, Ghiringhelli F, et al. Immunogenic death of colon cancer cells treated with oxaliplatin. Oncogene. 2010;29:482-91.

26. Panzarini E, Inguscio V, Fimia GM, Dini L. Rose Bengal Acetate PhotoDynamic Therapy (RBAc-PDT) induces exposure and release of Damage-Associated Molecular Patterns (DAMPs) in human HeLa cells. PLoS One. 2014;9:20-22.

27. Casares N, Pequignot MO, Tesniere A, Ghiringhelli F, Roux S, Chaput N, et al. Caspase-dependent immunogenicity of doxorubicin-induced tumor cell death. J Exp Med 2005;202:1691-701.

28. Dudek AM, Garg AD, Krysko DV, De Ruysscher D, Agostinis P. Inducers of immunogenic cancer cell death. Cytokine Growth Factor Rev 2013;24:319-33.

29. Buytaert E, Callewaert G, Hendrickx N, Scorrano L, Hartmann D, Missiaen L, et al Role of endoplasmic reticulum depletion and multidomain proapoptotic BAX and BAK proteins in shaping cell death after hypericin-mediated photodynamic therapy. FASEB J 2006;20:756-8.

30. Dewaele M, Martinet W, Rubio N, Verfaillie T, de Witte PA, Piette J, et al. Autophagy pathways activated in response to PDT contribute to cell resistance against ROS damage. J Cell Mol Med 2011;15:1402-14.

31. Garg AD, Dudek AM, Ferreira GB, Verfaillie T, Vandenabeele P, Krysko DV, et al. ROS-induced autophagy in cancer cells assists in evasion from determinants of immunogenic cell death. Autophagy. 2013;9:1292-307.

32. Van Vliet AR, Agostinis P. When under pressure, get closer: PERKing up membrane contact sites during ER stress. Biochem Soc Trans 2016;44:499-504.

33. Fucikova J, Becht E, Iribarren K, Goc J, Remark R, Damotte D, et al. Calreticulin Expression in Human Non-Small Cell Lung Cancers Correlates with Increased Accumulation of Antitumor Immune Cells and Favorable Prognosis. Cancer Res 2016;76:1746-56.

34. Hsu WM, Hsieh FJ, Jeng YM, Kuo ML, Chen CN, Lai DM, et al. Original article Calreticulin expression in neuroblastoma - a novel independent prognostic factor. Ann Oncol 2005;16:314-21.

35. Krysko DV, Garg AD, Kaczmarek A, Krysko O. Immunogenic cell death and DAMPs in cancer therapy. Nat Rev Cancer. 2012;12:860-75.

36. Prieto K, Paula M, Claudia L, Carlos U, Alméciga J, Susana D, et al. The delay in cell death caused by the induction of autophagy by P2Et extract is essential for the generation of immunogenic signals in melanoma cells. Apoptosis. 2020;25:875-88.

37. Rufo, N, Korovesis, D, Van Eygen, S, Derua, R, Garg, AD, Finotello, F, et al. Stressinduced inflammation evoked by immunogenic cell death is blunted by the IRE1a kinase inhibitor KIRA6 through HSP60 targeting. Cell Death Differ. (2021). 
38. Sprooten, J, Agostinis, P \& Garg, AD Type I interferons and dendritic cells in cancer immunotherapy. International Review of Cell and Molecular Biology 348, 217-62. (Elsevier Inc., 2019).

39. Wang X, Schoenhals JE, Li A, Valdecanas DR, Ye H, Zang F, et al. Suppression of type I IFN signaling in tumors mediates resistance to anti-PD-1 treatment that can be overcome by radiotherapy. Cancer Res 2017;77:839-50.

40. Lamberti MJ, Mentucci FM, Roselli E, Araya P, Rivarola VA, Rumie Vittar NB, et al. Photodynamic Modulation of Type 1 Interferon Pathway on Melanoma Cells Promotes Dendritic Cell Activation. Front Immunol 2019;10:1-12.

41. Zamanian M, Qader Hamadneh LA, Veerakumarasivam A, Abdul Rahman S, Shohaimi S, Rosli R. Calreticulin mediates an invasive breast cancer phenotype through the transcriptional dysregulation of p53 and MAPK pathways. Cancer Cell Int 2016;16:1-13.

42. Bianchi ME, Crippa MP, Manfredi AA, Mezzapelle R, Rovere Querini P, Venereau E. High-mobility group box 1 protein orchestrates responses to tissue damage via inflammation, innate and adaptive immunity, and tissue repair. Immunol Rev 2017;280:74-82.

43. Venereau E, Casalgrandi M, Schiraldi M, Antoine DJ, Cattaneo A, De Marchis F, et al. Mutually exclusive redox forms of HMGB1 promote cell recruitment or proinflammatory cytokine release. J Exp Med 2012;209:1519-28.

44. Petruk N, Tuominen S, Åkerfelt M, Mattsson J, Sandholm J, Nees M, et al. CD73 facilitates EMT progression and promotes lung metastases in triple-negative breast cancer. Sci Rep. 2021;11:6035.

45. Turiello R, Pinto A, Morello S. CD73: A Promising Biomarker in Cancer Patients. Front Pharmacol 2020;11:609931.

46. Leclerc BG, Charlebois R, Chouinard G, Allard B, Pommey S, Saad F, et al. CD73 Expression Is an Independent Prognostic Factor in Prostate Cancer. Clin Cancer Res 2016;22:158-66.

47. Messaoudi N, Cousineau I, Arslanian E, Henault D, Stephen D, VandenbrouckeMenu $\mathrm{F}$, et al. Prognostic value of CD73 expression in resected colorectal cancer liver metastasis. Oncoimmunology. 2020;9:1746138.

48. Synnestvedt K, Furuta GT, Comerford KM, Louis N, Karhausen J, Eltzschig HK, et al. Ecto-5'-nucleotidase (CD73) regulation by hypoxia-inducible factor-1 mediates permeability changes in intestinal epithelia. J Clin Invest 2002;110:993-1002.

49. Hayashi K, Nikolos F, Chan KS. Inhibitory DAMPs in immunogenic cell death and its clinical implications. Cell Stress. 2021;5:52-54.

50. Kohli, K, Pillarisetty, VG \& Kim, TS Key chemokines direct migration of immune cells in solid tumors. Cancer Gene Ther. 2021;29:10-21.

51. Chen C-J, Kono H, Golenbock D, Reed G, Akira S, Rock KL. Identification of a key pathway required for the sterile inflammatory response triggered by dying cells. Nat Med 2007;13:851-6.

52. Navratil JS, Sabatine JM, Ahearn JM. Apoptosis and immune responses to self. Rheum Dis Clin North Am. 2004;30:193-212.

53. Elkon KB. Apoptosis and autoimmunity. J Rheumatol Suppl. 1997;50:6-7.

54. Chang MK, Binder CJ, Miller YI, Subbanagounder G, Silverman GJ, Berliner JA, et al. Apoptotic cells with oxidation-specific epitopes are immunogenic and proinflammatory. J Exp Med 2004;200:1359-70.

55. Degterev A, Huang Z, Boyce M, Li Y, Jagtap P, Mizushima N, et al. Chemical inhibitor of nonapoptotic cell death with therapeutic potential for ischemic brain injury. Nat Chem Biol 2005;1:112-9.

56. Aaes TL, Kaczmarek A, Delvaeye T, De Craene B, De Koker S, Heyndrickx L, et al. Vaccination with Necroptotic Cancer Cells Induces Efficient Anti-tumor Immunity. Cell Rep. 2016;15:274-87.

57. Kaczmarek A, Vandenabeele P, Krysko DV. Review Necroptosis: The Release of Damage-Associated Molecular Patterns and Its Physiological Relevance. Immunity. 2013;38:209-23.

58. Tang R, Xu J, Zhang B, Liu J, Liang C, Hua J, et al. Ferroptosis, necroptosis, and pyroptosis in anticancer immunity. J Hematol Oncol. 2020;13:1-18.

59. Sprooten J, De Wijngaert $P$, Vanmeerbeek I, Martin S, Vangheluwe P, Schlenner $\mathrm{S}$, et al. Necroptosis in Immuno-Oncology and Cancer Immunotherapy. Cells. 2020;9:1823.

60. Aaes TL, Verschuere H, Kaczmarek A, Heyndrickx L, Wiernicki B, Delrue I, et al. Immunodominant AH1 Antigen-Deficient Necroptotic, but Not Apoptotic, Murine Cancer Cells Induce Antitumor Protection. J Immunol 2020;204:775-87.

61. Xie L, Xia L, Klaiber U, Sachsenmaier M, Hinz U, Bergmann F, et al. Effects of neoadjuvant FOLFIRONOX and gemcitabine-based chemotherapy on cancer cell survival and death in patients with pancreatic ductal adenocarcinoma. Oncotarget. 2019;10:7276-87.

62. Efimova I, Catanzaro E, Van Der Meeren L, Turubanova VD, Hammad H, Mishchenko TA, et al. Vaccination with early ferroptotic cancer cells induces efficient antitumor immunity. J Immunother Cancer. 2020;8:1-15.

63. Remijsen Q, Goossens V, Grootjans S, Van den Haute C, Vanlangenakker N, Dondelinger $\mathrm{Y}$, et al. Depletion of RIPK3 or MLKL blocks TNF-driven necroptosis and switches towards a delayed RIPK1 kinase-dependent apoptosis. Cell Death Dis. 2014;5:1-8.
64. Li, X. 乳鼠心肌提取 HHS Public Access. Physiol. Behav. 176, 139-148 (2016).

65. Hanahan D, Weinberg RA. Hallmarks of cancer: the next generation. Cell. 2011;144:646-74.

66. Fucikova J, Spisek R, Kroemer G, Galluzzi L. Calreticulin and cancer. Cell Res. 2021;31:5-16

67. Liu P, Zhao L, Loos F, Marty C, Xie W, Martins I, et al. Immunosuppression by Mutated Calreticulin Released from Malignant Cells. Mol Cell. 2020;77:748-60.e9.

68. Yang W, Xiu Z, He Y, Huang W, Li Y, Sun T. Bip inhibition in glioma stem cells promotes radiation-induced immunogenic cell death. Cell Death Dis. 2020;11:786.

69. Stupp R. Radiotherapy plus concomitant and adjuvant temozolomide for glioblastoma. N. Engl J Med. 2005;352:987-96.

70. Yang Y, He MZ, Li T, Yang X. MRI combined with PET-CT of different tracers to improve the accuracy of glioma diagnosis: a systematic review and metaanalysis. Neurosurg Rev 2019;42:185-95.

71. Poon MTC, Sudlow CLM, Figueroa JD, Brennan PM. Longer-term ( $\geq 2$ years) survival in patients with glioblastoma in population-based studies pre- and post-2005: a systematic review and meta-analysis. Sci Rep. 2020;10:11622.

72. Garg AD, Vandenberk L, Van Woensel M, Belmans J, Schaaf M, Boon L, et al. Preclinical efficacy of immune-checkpoint monotherapy does not recapitulate corresponding biomarkers-based clinical predictions in glioblastoma. Oncoimmunology. 2017;6:1-13.

73. Committee., E. N. Unified nomenclature for Eph family receptors and their ligands, the ephrins. Cell. 1997;90:403-4.

74. DeCordova S, Shastri A, Tsolaki AG, Yasmin H, Klein L, Singh SK, et al. Molecular Heterogeneity and Immunosuppressive Microenvironment in Glioblastoma. Front Immunol. 2020;11:1402.

75. Zhang X, Ding K, Wang J, Li X, Zhao P. Chemoresistance caused by the microenvironment of glioblastoma and the corresponding solutions. Biomed Pharmacother 2019;109:39-46.

76. Gupta K, Burns TC. Radiation-Induced Alterations in the Recurrent Glioblastoma Microenvironment: Therapeutic Implications. Front Oncol. 2018;8:503.

77. Wu J, Waxman DJ. Immunogenic chemotherapy: Dose and schedule dependence and combination with immunotherapy. Cancer Lett. 2018;419:210-21.

78. Zhou J, Wang G, Chen Y, Wang H, Hua Y, Cai Z. Immunogenic cell death in cancer therapy: Present and emerging inducers. J Cell Mol Med 2019;23:4854-65.

79. Jin M-Z, Wang X-P. Immunogenic Cell Death-Based Cancer Vaccines. Front Immunol. 2021;12:2030.

80. Cramer SW, Chen CC. Photodynamic Therapy for the Treatment of Glioblastoma. Front Surg 2020;6:81.

81. Eljamel S. Photodynamic applications in brain tumors: a comprehensive review of the literature. Photodiagnosis Photodyn Ther. 2010;7:76-85.

82. Cheng $\mathrm{Y}$, Cheng $\mathrm{H}$, Jiang $\mathrm{C}$, Qiu X, Wang $\mathrm{K}$, Huan W, et al. Perfluorocarbon nanoparticles enhance reactive oxygen levels and tumour growth inhibition in photodynamic therapy. Nat Commun 2015;6:8785.

83. Freitas I. Facing hypoxia: a must for photodynamic therapy. J Photochem Photobiol B 1988;2:281-2.

84. Larue L, Myrzakhmetov B, Ben-Mihoub A, Moussaron A, Thomas N, Arnoux P, et al. Fighting Hypoxia to Improve PDT. Pharm (Basel). 2019;12:163.

85. Shen Z, Ma Q, Zhou X, Zhang G, Hao G, Sun Y, et al. Strategies to improve photodynamic therapy efficacy by relieving the tumor hypoxia environment. NPG Asia Mater. 2021;13:39.

86. Dang J, He H, Chen D, Yin L. Manipulating tumor hypoxia toward enhanced photodynamic therapy (PDT). Biomater Sci 2017;5:1500-11.

87. Hadjipanayis CG, Widhalm G, Stummer W. What is the Surgical Benefit of Utilizing 5-Aminolevulinic Acid for Fluorescence-Guided Surgery of Malignant Gliomas? Neurosurgery. 2015;77:663-73.

88. Galluzzi L, Kepp O, Kroemer G. Immunogenic cell death in radiation therapy. Oncoimmunology. 2013;2:e26536.

89. Frey B, Rubner Y, Kulzer L, Werthmöller N, Weiss E-M, Fietkau R, et al. Antitumor immune responses induced by ionizing irradiation and further immune stimulation. Cancer Immunol Immunother 2014;63:29-36.

90. Matsumura S, Demaria S. Up-regulation of the pro-inflammatory chemokine CXCL16 is a common response of tumor cells to ionizing radiation. Radiat Res 2010;173:418-25.

91. Lugade AA, Sorensen EW, Gerber SA, Moran JP, Frelinger JG, Lord EM. Radiationinduced IFN-gamma production within the tumor microenvironment influences antitumor immunity. J Immunol 2008;180:3132-9.

92. Naulaerts, S, Borras, DM, Martinez, AA, Messiaen, J, Van Herck, Y, Gelens, L, et al. Immunogenomic, single-cell and spatial dissection of $\mathrm{CD}^{+} \mathrm{T}$ cell exhaustion reveals critical determinants of cancer immunotherapy. bioRxiv 2021.11.22.468617 (2021)

93. Vaes, RDW, Hendriks, LEL, Vooijs, M \& De Ruysscher, D Biomarkers of Radiotherapy-Induced Immunogenic Cell Death. Cells 10, (2021). 
94. Demaria S, Vanpouille-Box C, Formenti SC, Adams S. The TLR7 agonist imiquimod as an adjuvant for radiotherapy-elicited in situ vaccination against breast cancer. Oncoimmunology. 2013;2:e25997.

95. Rubner Y, Muth C, Strnad A, Derer A, Sieber R, Buslei R, et al. Fractionated radiotherapy is the main stimulus for the induction of cell death and of Hsp70 release of p53 mutated glioblastoma cell lines. Radiat Oncol 2014;9:89.

96. Pasi F, Paolini A, Nano R, Di Liberto R, Capelli E. Effects of single or combined treatments with radiation and chemotherapy on survival and danger signals expression in glioblastoma cell lines. Biomed Res Int 2014;2014:453497.

97. Bugaut $H$, Bruchard $M$, Berger $H$, Derangère $V$, Odoul $L$, Euvrard $R$, et al. Bleomycin exerts ambivalent antitumor immune effect by triggering both immunogenic cell death and proliferation of regulatory T cells. PLoS One. 2013;8:e65181.

98. Lau TS, Chan LKY, Man GCW, Wong CH, Lee JHS, Yim SF, et al. Paclitaxel Induces Immunogenic Cell Death in Ovarian Cancer via TLR4/IKK2/SNARE-Dependent Exocytosis. Cancer Immunol Res 2020;8:1099-111.

99. Du B, Waxman DJ. Medium dose intermittent cyclophosphamide induces immunogenic cell death and cancer cell autonomous type I interferon production in glioma models. Cancer Lett. 2020;470:170-80.

100. Roberts NB, Alqazzaz A, Hwang JR, Qi X, Keegan AD, Kim AJ, et al. Oxaliplatin disrupts pathological features of glioma cells and associated macrophages independent of apoptosis induction. J Neurooncol 2018;140:497-507.

101. Schäfer N, Tichy J, Thanendrarajan S, Kim Y, Stuplich M, Mack F, et al. Ifosfamide, carboplatin and etoposide in recurrent malignant glioma. Oncology. 2011;80:330-2.

102. Yamano T, Kubo S, Fukumoto M, Yano A, Mawatari-Furukawa Y, Okamura H, et al. Whole cell vaccination using immunogenic cell death by an oncolytic adenovirus is effective against a colorectal cancer model. Mol Ther oncolytics. 2016;3:16031.

103. Workenhe ST, Mossman KL. Oncolytic virotherapy and immunogenic cancer cell death: sharpening the sword for improved cancer treatment strategies. Mol Ther 2014;22:251-6.

104. Bommareddy PK, Zloza A, Rabkin SD, Kaufman HL. Oncolytic virus immunotherapy induces immunogenic cell death and overcomes STING deficiency in melanoma. Oncoimmunology. 2019;8:1591875.

105. Zhao X, Yang K, Zhao R, Ji T, Wang X, Yang X, et al. Inducing enhanced immunogenic cell death with nanocarrier-based drug delivery systems for pancreatic cancer therapy. Biomaterials. 2016;102:187-97.

106. Kinoh H, Quader S, Shibasaki H, Liu X, Maity A, Yamasoba T, et al. Translational Nanomedicine Boosts Anti-PD1 Therapy to Eradicate Orthotopic PTEN-Negative Glioblastoma. ACS Nano. 2020;14:10127-40.

107. Nuccitelli R, McDaniel A, Anand S, Cha J, Mallon Z, Berridge JC, et al. Nano-Pulse Stimulation is a physical modality that can trigger immunogenic tumor cell death. J Immunother cancer. 2017;5:32.

108. Kobayashi H, Choyke PL. Near-Infrared Photoimmunotherapy of Cancer. Acc Chem Res 2019;52:2332-9.

109. Fucikova J, Moserova I, Truxova I, Hermanova I, Vancurova I, Partlova S, et al. High hydrostatic pressure induces immunogenic cell death in human tumor cells. Int J cancer. 2014;135:1165-77.

110. van Leeuwen CM, Crezee J, Oei AL, Franken NAP, Stalpers LJA, Bel A, et al. The effect of time interval between radiotherapy and hyperthermia on planned equivalent radiation dose. Int J Hyperth J Eur Soc Hyperthermic Oncol North Am Hyperth Gr 2018;34:901-9.

111. Westermann AM, Jones EL, Schem B-C, van der Steen-Banasik EM, Koper P, Mella $\mathrm{O}$, et al. First results of triple-modality treatment combining radiotherapy, chemotherapy, and hyperthermia for the treatment of patients with stage IIB, III, and IVA cervical carcinoma. Cancer. 2005;104:763-70.

112. Atanackovic D, Nierhaus A, Neumeier M, Hossfeld DK, Hegewisch-Becker S. 41.8 degrees $C$ whole body hyperthermia as an adjunct to chemotherapy induces prolonged $\mathrm{T}$ cell activation in patients with various malignant diseases. Cancer Immunol Immunother 2002;51:603-13.

113. Feyerabend T, Wiedemann GJ, Jäger B, Vesely H, Mahlmann B, Richter E. Local hyperthermia, radiation, and chemotherapy in recurrent breast cancer is feasible and effective except for inflammatory disease. Int J Radiat Oncol Biol Phys 2001:49:1317-25.

114. Takahashi I, Emi Y, Hasuda S, Kakeji Y, Maehara Y, Sugimachi K. Clinical application of hyperthermia combined with anticancer drugs for the treatment of solid tumors. Surgery. 2002;131:S78-84.

115. Thomas JG, Rao G, Kew Y, Prabhu SS. Laser interstitial thermal therapy for newly diagnosed and recurrent glioblastoma. Neurosurg Focus. 2016;41:E12.

116. Lipsman N, Schwartz ML, Huang Y, Lee L, Sankar T, Chapman M. MR-guided focused ultrasound thalamotomy for essential tremor: a proof-of-concept study. Lancet Neurol. 2013;12:462-8.

117. Coluccia, D, Fandino, J, Schwyzer, L, O'Gorman, R, Remonda, L \& Anon, J First noninvasive thermal ablation of a brain tumor with MR-guided focused ultrasound. J. Ther. ultrasound 2, (2014).
118. McDannold N, Clement G, Black P, Jolesz F, Hynynen K. Transcranial MRI-guided focused ultrasound surgery of brain tumors: Initial findings in three patients. Neurosurgery. 2010;66:323-32.

119. Ram Z, Cohen ZR, Harnof S, Tal S, Faibel M, Nass D. Magnetic resonance imaging-guided, high-intensity focused ultrasound for brain tumor therapy. Neurosurgery. 2006;59:949-56.

120. Quadri SA, Waqas M, Khan I, Khan MA, Suriya SS, Farooqui M, et al. Highintensity focused ultrasound: past, present, and future in neurosurgery. Neurosurg Focus FOC. 2018;44:E16.

121. Medel R, Monteith SJ, Elias WJ, Eames M, Snell J, Sheehan JP. Magnetic resonance-guided focused ultrasound surgery: part 2: a review of current and future applications. Neurosurgery. 2012;71:755-63.

122. Pozzi C, Cuomo A, Spadoni I, Magni E, Silvola A, Conte A, et al. The EGFR-specific antibody cetuximab combined with chemotherapy triggers immunogenic cell death. Nat Med 2016;22:624-31.

123. Stupp R, Wong ET, Kanner AA, Steinberg D, Engelhard $H$, Heidecke $V$, et al. NovoTTF-100A versus physician's choice chemotherapy in recurrent glioblastoma: a randomised phase III trial of a novel treatment modality. Eur J Cancer. 2012;48:2192-202.

124. Stupp R, Taillibert S, Kanner A, Read W, Steinberg D, Lhermitte B, et al. Effect of Tumor-Treating Fields Plus Maintenance Temozolomide vs Maintenance Temozolomide Alone on Survival in Patients With Glioblastoma: A Randomized Clinical Trial. JAMA. 2017;318:2306-16.

125. Kim EH, Song HS, Yoo SH, Yoon M. Tumor treating fields inhibit glioblastoma cell migration, invasion and angiogenesis. Oncotarget. 2016;7:65125-36.

126. Wong ET, Lok E, Swanson KD. Alternating Electric Fields Therapy for Malignant Gliomas: From Bench Observation to Clinical Reality. in. Prog Neurological Surg. 2017;32:180-95.

127. Garg AD, Vandenberk L, Koks C, Verschuere T, Boon L, Van Gool SW, et al. Dendritic cell vaccines based on immunogenic cell death elicit danger signals and T cell-driven rejection of high-grade glioma. Sci Transl Med 2016;8:328ra27.

128. Garg AD, Elsen $S$, Krysko DV, Vandenabeele $P$, de Witte $P$, Agostinis P. Resistance to anticancer vaccination effect is controlled by a cancer cell-autonomous phenotype that disrupts immunogenic phagocytic removal. Oncotarget. 2015;6:26841-60.

129. Vacchelli E, Sistigu A, Yamazaki T, Vitale I, Zitvogel L, Kroemer G. Autocrine signaling of type 1 interferons in successful anticancer chemotherapy. Oncoimmunology. 2015;4:2-5.

130. Yang H, Yamazaki T, Pietrocola F, Zhou H, Zitvogel L, Ma Y, et al. Improvement of immunogenic chemotherapy by STAT3 inhibition. Oncoimmunology. 2016;5:1-3.

131. García-Romero N, Palacín-Aliana I, Esteban-Rubio S, Madurga R, Rius-Rocabert S, Carrión-Navarro J, et al. Newcastle Disease Virus (NDV) Oncolytic Activity in Human Glioma Tumors Is Dependent on CDKN2A-Type I IFN Gene Cluster Codeletion. Cells. 2020;9:1-17.

132. Zhang J, Chen $C$, Li A, Jing W, Sun $P$, Huang $X$, et al. Immunostimulant hydroge for the inhibition of malignant glioma relapse post-resection. Nat Nanotechnol 2021;16:538-48.

133. Chiocca EA, Nassiri F, Wang J, Peruzzi P, Zadeh G. Viral and other therapies for recurrent glioblastoma: is a 24-month durable response unusual? Neuro Oncol 2019:21:14-25.

134. Pelin A, Foloppe J, Petryk J, Singaravelu R, Hussein M, Gossart F, et al. Deletion of Apoptosis Inhibitor F1L in Vaccinia Virus Increases Safety and Oncolysis for Cancer Therapy. Mol Ther oncolytics. 2019;14:246-52.

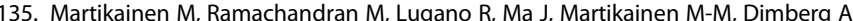
et al. IFN-I-tolerant oncolytic Semliki Forest virus in combination with anti-PD1 enhances $T$ cell response against mouse glioma. Mol Ther oncolytics. 2021;21:37-46

136. Koks CA, Garg AD, Ehrhardt M, Riva M, Vandenberk L, Boon L, et al. Newcastle disease virotherapy induces long-term survival and tumor-specific immune memory in orthotopic glioma through the induction of immunogenic cell death. Int J cancer. 2015;136:E313-25.

137. Li T-F, Li K, Zhang Q, Wang C, Yue Y, Chen Z, et al. Dendritic cell-mediated delivery of doxorubicin-polyglycerol-nanodiamond composites elicits enhanced anti-cancer immune response in glioblastoma. Biomaterials. 2018;181:35-52.

138. Pizzocri M, Re F, Stanzani E, Formicola B, Tamborini M, Lauranzano $E$, et al Radiation and adjuvant drug-loaded liposomes target glioblastoma stem cells and trigger in-situ immune response. Neuro-Oncol Adv 2021;3:vdab076.

139. Park S, Hatanpaa KJ, Xie Y, Mickey BE, Madden CJ, Raisanen JM, et al. The receptor interacting protein 1 inhibits p53 induction through NF-kappaB activation and confers a worse prognosis in glioblastoma. Cancer Res. 2009;69: 2809-16.

140. Teo, ZL, Versaci, S, Dushyanthen, $S$, Caramia, F, Savas, $P$, Mintoff, $C P$, et al. Combined CDK4 / 6 and PI3K a Inhibition Is Synergistic and Immunogenic in Triple-Negative Breast Cancer. 77, (2017). 
141. Franco-Molina MA, Santana-Krímskaya SE, Madrigal-De-león LM, CoronadoCerda EE, Zárate-Triviño DG, Hernández-Martínez SP, et al. Evaluation of the cytotoxic and immunogenic potential of temozolamide, panobinostat, and lophophora williamsii extract against c6 glioma cells. EXCLI J. 2021;20:614-24.

142. Villamañan, L, Martínez-Escardó, L, Arús, C, Yuste, VJ \& Candiota, AP Successful Partnerships: Exploring the Potential of Immunogenic Signals Triggered by TMZ, CX-4945, and Combined Treatment in GL261 Glioblastoma Cells. Int. J. Mol. Sci. 22, (2021).

143. Eljamel MS, Goodman C, Moseley H. ALA and Photofrin fluorescence-guided resection and repetitive PDT in glioblastoma multiforme: a single centre Phase III randomised controlled trial. Lasers Med Sci 2008;23:361-7.

144. Beck TJ, Kreth FW, Beyer W, Mehrkens JH, Obermeier A, Stepp H, et al. Interstitial photodynamic therapy of nonresectable malignant glioma recurrences using 5-aminolevulinic acid induced protoporphyrin IX. Lasers Surg Med 2007;39: 386-93.

145. Johansson A, Faber F, Kniebühler G, Stepp H, Sroka R, Egensperger R, et al. Protoporphyrin IX fluorescence and photobleaching during interstitial photodynamic therapy of malignant gliomas for early treatment prognosis. Lasers Surg Med 2013;45:225-34.

146. Schwartz C, Rühm A, Tonn J-C, Kreth S, Kreth F-W. SURG-25: INTERSTITIAL PHOTODYNAMIC THERAPY OF DE-NOVO GLIOBLASTOMA MULTIFORME WHO IV. Neuro Oncol 2015;17:v219-v220.

147. Sampson JH, Archer GE, Mitchell DA, Heimberger AB, Herndon JE, Lally-Goss D, et al. An epidermal growth factor receptor variant III-targeted vaccine is safe and immunogenic in patients with glioblastoma multiforme. Mol Cancer Ther 2009;8:2773 LP-2779.

148. Mrugala MM, Engelhard HH, Dinh Tran D, Kew Y, Cavaliere R, Villano JL, et al. Clinical Practice Experience With NovoTTF-100A ${ }^{\mathrm{TM}}$ System for Glioblastoma: The Patient Registry Dataset (PRiDe). Semin Oncol 2014;41:S4-S13.

149. Yu JS, Wheeler CJ, Zeltzer PM, Ying H, Finger DN, Lee PK, et al. Vaccination of malignant glioma patients with peptide-pulsed dendritic cells elicits systemic cytotoxicity and intracranial T-cell infiltration. Cancer Res. 2001;61:842-7.

150. Yamanaka R, Abe T, Yajima N, Tsuchiya N, Homma J, Kobayashi T, et al. Vaccination of recurrent glioma patients with tumour lysate-pulsed dendritic cells elicits immune responses: results of a clinical phase I/II trial. $\mathrm{Br} J$ Cancer. 2003;89:1172-9.

151. Yu JS, Liu G, Ying $H$, Yong WH, Black KL, Wheeler CJ. Vaccination with tumor lysate-pulsed dendritic cells elicits antigen-specific, cytotoxic T-cells in patients with malignant glioma. Cancer Res. 2004;64:4973-9.

152. Liau LM, Prins RM, Kiertscher SM, Odesa SK, Kremen TJ, Giovannone AJ, et al. Dendritic cell vaccination in glioblastoma patients induces systemic and intracranial T-cell responses modulated by the local central nervous system tumor microenvironment. Clin Cancer Res J Am Assoc Cancer Res 2005;11:5515-25.

153. De Vleeschouwer S, Fieuws S, Rutkowski S, Van Calenbergh F, Van Loon J, Goffin J, et al. Postoperative adjuvant dendritic cell-based immunotherapy in patients with relapsed glioblastoma multiforme. Clin Cancer Res J Am Assoc Cancer Res 2008;14:3098-104.

154. Wheeler CJ, Black KL, Liu G, Mazer M, Zhang X, Pepkowitz S, et al. Vaccination elicits correlated immune and clinical responses in glioblastoma multiforme patients. Cancer Res. 2008;68:5955-64.

155. Chang C-N, Huang Y-C, Yang D-M, Kikuta K, Wei K-J, Kubota T, et al. A phase I/II clinical trial investigating the adverse and therapeutic effects of a postoperative autologous dendritic cell tumor vaccine in patients with malignant glioma. J Clin Neurosci J Neurosurg Soc Australas 2011;18:1048-54.

156. Fadul CE, Fisher JL, Hampton TH, Lallana EC, Li Z, Gui J, et al. Immune response in patients with newly diagnosed glioblastoma multiforme treated with intranodal autologous tumor lysate-dendritic cell vaccination after radiation chemotherapy. J Immunother 2011;34:382-9.

157. Ardon H, Van Gool SW, Verschuere T, Maes W, Fieuws S, Sciot R, et al. Integration of autologous dendritic cell-based immunotherapy in the standard of care treatment for patients with newly diagnosed glioblastoma: results of the HGG2006 phase I/II trial. Cancer Immunol Immunother 2012;61:2033-44.

158. Cho D-Y, Yang W-K, Lee H-C, Hsu D-M, Lin H-L, Lin S-Z, et al. Adjuvant immunotherapy with whole-cell lysate dendritic cells vaccine for glioblastoma multiforme: a phase II clinical trial. World Neurosurg. 2012;77:736-44.

159. Akiyama $Y$, Oshita $C$, Kume A, lizuka A, Miyata H, Komiyama $M$, et al. a-type-1 polarized dendritic cell-based vaccination in recurrent high-grade glioma: a phase I clinical trial. BMC Cancer. 2012;12:623.

160. Jie X, Hua L, Jiang W, Feng F, Feng G, Hua Z. Clinical application of a dendritic cell vaccine raised against heat-shocked glioblastoma. Cell Biochem Biophys 2012;62:91-99.

161. Shah AH, Bregy A, Heros DO, Komotar RJ, Goldberg J. Dendritic cell vaccine for recurrent high-grade gliomas in pediatric and adult subjects: clinical trial protocol. Neurosurgery. 2013;73:863-7.
162. Phuphanich S, Wheeler CJ, Rudnick JD, Mazer M, Wang H, Nuño MA, et al. Phase I trial of a multi-epitope-pulsed dendritic cell vaccine for patients with newly diagnosed glioblastoma. Cancer Immunol Immunother 2013;62: 125-35.

163. Vik-Mo EO, Nyakas M, Mikkelsen BV, Moe MC, Due-Tønnesen P, Suso EMI, et al. Therapeutic vaccination against autologous cancer stem cells with mRNAtransfected dendritic cells in patients with glioblastoma. Cancer Immunol Immunother 2013;62:1499-509.

164. Sakai K, Shimodaira S, Maejima S, Udagawa N, Sano K, Higuchi Y, et al. Dendritic cell-based immunotherapy targeting Wilms' tumor 1 in patients with recurrent malignant glioma. J Neurosurg 2015;123:989-97.

165. Hunn MK, Bauer E, Wood CE, Gasser O, Dzhelali M, Ancelet LR, et al. Dendritic cell vaccination combined with temozolomide retreatment: results of a phase I trial in patients with recurrent glioblastoma multiforme. J Neurooncol 2015;121:319-29.

166. Akasaki Y, Kikuchi T, Homma S, Koido S, Ohkusa T, Tasaki T, et al. Phase I/II trial of combination of temozolomide chemotherapy and immunotherapy with fusions of dendritic and glioma cells in patients with glioblastoma. Cancer Immunol Immunother 2016;65:1499-509.

167. Batich KA, Reap EA, Archer GE, Sanchez-Perez L, Nair SK, Schmittling RJ, et al. Long-term Survival in Glioblastoma with Cytomegalovirus pp65-Targeted Vaccination. Clin Cancer Res J Am Assoc Cancer Res 2017:23:1898-909.

168. Inogés S, Tejada S, de Cerio AL-D, Gállego Pérez-Larraya J, Espinós J, Idoate MA, et al. A phase II trial of autologous dendritic cell vaccination and radiochemotherapy following fluorescence-guided surgery in newly diagnosed glioblastoma patients. J Transl Med 2017;15:104.

169. Liau LM, Ashkan K, Tran DD, Campian JL, Trusheim JE, Cobbs CS, et al. First results on survival from a large Phase 3 clinical trial of an autologous dendritic cell vaccine in newly diagnosed glioblastoma. J Transl Med 2018;16:142.

170. Yao Y, Luo F, Tang C, Chen D, Qin Z, Hua W, et al. Molecular subgroups and B7$\mathrm{H} 4$ expression levels predict responses to dendritic cell vaccines in glioblastoma: an exploratory randomized phase II clinical trial. Cancer Immunol Immunother 2018;67:1777-88.

171. Reap EA, Suryadevara CM, Batich KA, Sanchez-Perez L, Archer GE, Schmittling RJ, et al. Dendritic Cells Enhance Polyfunctionality of Adoptively Transferred T Cells That Target Cytomegalovirus in Glioblastoma. Cancer Res. 2018;78: 256-64.

172. Wen PY, Reardon DA, Armstrong TS, Phuphanich S, Aiken RD, Landolfi JC, et al. A Randomized Double-Blind Placebo-Controlled Phase II Trial of Dendritic Cell Vaccine ICT-107 in Newly Diagnosed Patients with Glioblastoma. Clin Cancer Res J Am Assoc Cancer Res 2019;25:5799-807.

173. Wang Q-T, Nie Y, Sun S-N, Lin T, Han R-J, Jiang J, et al. Tumor-associated antigen-based personalized dendritic cell vaccine in solid tumor patients. Cancer Immunol Immunother 2020;69:1375-87.

174. Mitsuya K, Akiyama Y, lizuka A, Miyata H, Deguchi S, Hayashi N, et al. Alpha-type1 Polarized Dendritic Cell-based Vaccination in Newly Diagnosed High-grade Glioma: A Phase II Clinical Trial. Anticancer Res. 2020;40:6473-84.

\section{AUTHOR CONTRIBUTIONS}

$B D$ and $Y Y$ contributed equally to the literature search, text writing, and editing the text based on the remarks of all co-authors. SDV supervised the text writing, corrected the text, and gave feedback after every text version. PA corrected the text and gave feedback after every text version. FDS and AG gave feedback after every text version.

\section{COMPETING INTERESTS}

The authors declare no competing interests.

\section{ADDITIONAL INFORMATION}

Correspondence and requests for materials should be addressed to Steven De Vleeschouwer

Reprints and permission information is available at http://www.nature.com/ reprints

Publisher's note Springer Nature remains neutral with regard to jurisdictional claims in published maps and institutional affiliations. 
Open Access This article is licensed under a Creative Commons Ac) Attribution 4.0 International License, which permits use, sharing,
adaptation, distribution and reproduction in any medium or format, as long as you give appropriate credit to the original author(s) and the source, provide a link to the Creative Commons license, and indicate if changes were made. The images or other third party material in this article are included in the article's Creative Commons license, unless indicated otherwise in a credit line to the material. If material is not included in the article's Creative Commons license and your intended use is not permitted by statutory regulation or exceeds the permitted use, you will need to obtain permission directly from the copyright holder. To view a copy of this license, visit http://creativecommons. org/licenses/by/4.0/.

(c) The Author(s) 2022 